\title{
Nature vs policy: drought and famine in the northeast of Brazil, 1877-79
}

\author{
Gerenciamento dos resíduos têxteis pré-consumo da \\ indústria de confecção do vestuário em Teresina/PI
}

James Augusto Pires Tiburcio ${ }^{1}$

${ }^{1} \mathrm{PhD}$ in Sustainable Development, Director, Instituto de Reflorestamento Eden, São Luís, MA, Brazil

E-mail: james.tiburcio@edenprojects.org

doi:10.18472/SustDeb.v12n3.2021.40293

\section{Received: 02/10/2021}

Accepted: 20/11/2021

\begin{abstract}
Droughts followed by famines were common in Brazil, mainly in Northeast Brazil, until the 1980s and were frequently devastating, destroying livelihoods. A succession of droughts resulted in harvest failure, triggering famines in some cases. Famine-like conditions prevailed mainly in the 1877-79 Grande Seca (Great Drought), in which many died of malnutrition-related causes. In subsequent droughts, faminelike conditions reoccurred, but the extent of starvation-induced deaths declined to almost zero. Do only available political theories and known natural and socio-political factors, such as climate, topography, and market viability, provide sufficient data to investigate the causes of the drought of 1877-1879? The author concludes that there is little or no research, accumulated knowledge and information on the possible factors that satisfactorily explain why the drought and famine episodes were so impactful in that period.
\end{abstract}

Keywords: Drought. Famine. Northeast of Brazil. Grande Seca. Geographical Nature.

\section{RESUMO}

Secas seguidas de fome eram comuns no Brasil, especialmente no Nordeste, até a década de 1980, sendo frequentemente devastadoras, destruindo meios de subsistência. Uma sucessão de secas resultou no fracasso da colheita, desencadeando carestia em alguns casos. Condições semelhantes à carestia prevaleceram particularmente na Grande Seca (Grande Seca) de 1877-79, na qual muitos morreram de causas relacionadas à desnutrição. Nas secas subsequentes, condições semelhantes à carestia voltaram a ocorrer, mas a extensão das mortes induzidas pela fome caiu para quase zero. Apenas as teorias políticas disponíveis e fatores naturais e sociopolíticos conhecidos, como clima, topografia e viabilidade de mercado, fornecem dados suficientes para uma investigação das causas da carestia em meio à seca de 1877-1879? A conclusão do autor é que há pouca ou nenhuma pesquisa, conhecimento acumulado e informações sobre os possíveis fatores que explicam de forma satisfatória porque os episódios de seca e fome foram tão impactantes naquele período.

Palavras-chave: Seca. Fome. Nordeste do Brasil. Grande Seca. Natureza geográfica.

\section{INTRODUCTION}

Most analyses of droughts and destruction of livelihoods and the famines that follow are a mix of Malthusian traditions of "natural" versus "manmade". Roy (2016) argues that, in Indianist literature, 
manmade can also mean cultural dogmas that moulded the scope of private charity aimed at mitigating the consequences of disasters. Robust evidence and analyses show that most Brazilian droughts were almost entirely caused by the El Niño Southern Oscillation (Enso) phenomenon (SINGH et al., 2018). In $20^{\text {th }}$ century Brazil, there was much debate concerning whether the resulting famines were natural or manmade. A preexisting history of bad diet and malnutrition is often blamed for devastating effects following demand and supply shocks (ROY, 2016). Manmade ones usually refer to famines with a politically motivated action that shifts food supply away from one group to another, especially as a function of state action or inaction behind them. The state's role cannot be downplayed as famine relief, in the sense of an organised effort to reduce starvation in a region affected by famine, usually is not priced nor refused by anyone (DENG; MINEAR, 1992).

Some have argued that state famine relief has on occasion failed in situations of, for example, protracted political crises, which resulted in sectarian or predatory reactions to socioeconomic stress and marginalisation (DUFFIELD, 1994). Others have blamed ideological biases that prevent states from doing more, for example, in the Great Famine in Ireland or the famines in India during the British Raj period (STAHL, 2016).

Despite being among one of the most populated semiarid regions globally, overpopulation was never a significant factor in analyses of the Brazilian Sertão famines, despite some noteworthy mentions (SENA et al., 2018). Bertola and Ocampo (2012) mention overpopulation in the Brazilian Northeast; however, contemporaries saw the Sertão as a depopulated expanse, victimised by diseases and droughts (BLAKE, 2003). The Northeast population was and still is the second largest in Brazil. However, the demographic density of this region has always been low as it occupies an extensive territory. Estimates of the pre-conquest population of Brazil as a whole and that of the Northeast are problematic. Most probably, the whole territory's population was somewhere between 1 and 3 million (MADDISON, 1992). And there was, admittedly, a demographic collapse of the first peoples' population in the first 2 centuries of European presence (NEWSON, 1993). Nonetheless, many have suffered one or another sort of stigma from other regions since the first documented migrations triggered by droughts (ALBUQUERQUE JÚNIOR, 2017). In the 1870s, the Northeast of Brazil was not regarded as a separate region as it came to be in the $20^{\text {th }}$ century (MELO, 1984). Instead, it was part of the provinces of the North, an area that stretched from the Amazonas to Bahia, in opposition to the South that went from Espírito Santo to Rio Grande (GREENFIELD, 1992).

In the Brazilian backwaters, state relief in the $20^{\text {th }}$ century was not hampered by an ideology that defended weak relief; there were no wars, despotic regimes, or even state collapses. There were political factors, as there were no absolute and general food shortage circumstances and no deliberate obstacles to the supply and distribution of food (Ó GRÁDA, 2007). However, the vulnerable agrarian environment was always present, mainly due to the intellectual influence of positivist faith in the use of technical expertise, without any consideration for the socio-economic context in which the same technique would be deployed (BUCKLEY, 2010).

I use literature and theoretical review to identify gaps in current research understanding of the political theories, natural and political factors that investigate the causes of the drought of 1877-1879. In so doing, I locate my research within this context, tracing progression in the field, identifying gaps, and suggesting how future research may elucidate present contradictory conclusions. The limitations of this research article are closely linked to the limited number of consulted bibliographies, characteristic of non-systematic reviews. However, the perspectives presented are representative of state of art in the field.

\section{GEOGRAPHICAL APPROACHES TO BRAZILIAN FAMINE CONDITIONS: TESTING THE USEFULNESS OF MANMADE VERSUS NATURAL ANALYSES}

As in most of Asia, Africa, and the Americas, records of droughts and famines became available following the European invasion, though their occurrence has an unknowable unrecorded history. In Brazil's case, systematic documentation is very recent, an innovation brought by the Portuguese crown 
in 1808 and only systematised and institutionalised in the $20^{\text {th }}$ century. A bias regarding manmade analyses is intrinsically overlapped by a European colonial reading of all phenomena (ALVES, 2003).

Droughts which resulted in famine-like conditions that led to deaths were more frequent in the 19th century, still happened in the $20^{\text {th }}$ and ceased altogether in the $21^{\text {st }}$ (at least so far). In this regard, the region followed the global trend. A decline in famines is inversely correlated with population growth, resulting in a permanent decrease in mortality rates and a demographic transition. A simple test to verify the usefulness of the manmade versus natural analyses as causal models should explain the frequency of famine-like situations and the rarity of a single factor. In the Northeast of Brazil, the last drought that resulted in famine-like cases was the 1979-83 (or 1985) (BRITO et al., 2018).

Documented episodes of famine-like conditions in Brazil are available from the beginning of the Portuguese invasion. The first known record was made in a letter by a Jesuit Roman Catholic priest, Father Antonio Pires in 1552 (VILLA, 2000). In his Carta de Pernambuco em 5 de junho de 1552 aos Padres de Portugal, Pires, cited by Navarro (1988), affirms that, "[a]nd so there were four or five years that it didn't rain on it, and this year it rained so much that they collected so much food that it is staggering, and those of the land are persuaded that because of the sins that it didn't rain: They praise God a lot" (NAVARRO, 1988, p. 123 [author's translation]).

More than 30 years later, another Jesuit, Fernão Cardim, describes a drought in Brazil.

The year of ' 83 was such a great dryness and barrenness in this province (a rare and unaccustomed thing, because it is a land of continuous rains) the water mills did not grind much time. The plantations of sugar cane and cassava were dried up, where there was a great famine, mainly in the backlands of Pernambuco; after that, they descended from the hinterland, hunger-stricken, and were assisted by the whites some four or five thousand Indians. But after that work of famine, those who could have turned to the hinterland, except those who stayed with the whites, or by their own, or without their will (CARDIM, 1980, p. 69 [author's translation]).

Seventeenth-century records are scarce and vary about dates. Eighteenth-century records are found on the occurrence of ten droughts with several divergences regarding locations and dates, the most accepted ones: 1709/1711 (Maranhão), 1721-25 or 1723-27 (Ceará and Rio Grande do Norte), 1736$37,1745-46,1754,1760,1766,1772,1776-78$ (a severe drought that coincided with an outbreak of smallpox) and 1791-93, a lack that transformed part of the population into beggars.

In the eighteenth century, there was a drought in every decade in the then Northern Provinces (GONÇALVES, 2018). For four times a period of lack of five consecutive years has been recorded in contemporary Brazilian history: 1876 to 1880 , then again at the beginning of the $20^{\text {th }}$ century, from 1901 to 1905,1929 to 1933 , and 1979 to 1983 . However, the most extended period ever registered took place between 2012 to 2017 (BRITO et al., 2018).

In the last quarter of the nineteenth century, between 1877 and 1878, the Grande Seca caused the deaths of between 400 and 500 thousand people. Of the 800 thousand who inhabited the Northeastern region, 168 thousand migrated to other parts of Brazil. In tandem with parts of Asia and Africa, it was part of the deadliest disaster ever registered, 30 to 60 million people worldwide were victimised, and there were enduring consequences (SINGH et al., 2018).

In Northeast Brazil, a significant crop failure occurred, intensified by an incipient agricultural management environment, overgrazing, sharecropping, inadequate preparation, and government response (CAMPOS, 2015). The twentieth century was not much better as, for example, between 1979 and 1984, there were famine-related deaths, apart from an unknown number of infirmities derived from malnutrition, especially among children, as a direct result of the drought which scorched the Brazilian 
Northeast in those years (VASCONCELOS, 2020). Interestingly, Brazil does not figure in the 20th-century famines death table compiled by Hasell and Roser (2013), although the 1896-1900 Famine is listed.

Before the Famine of 1877-79, an unknown but significant percentage of the population was already suffering from a chronic state of nutritional deficiencies that, with a little less food, would lead to hunger and death from diseases associated with malnutrition. Many of those affected - the flagelados - were already on the brink of the precipice, living debilitated lives in a region that had not experienced drought since the 1840s but had an economy in crisis due to the general fall in the prices of exported products (FURTADO, 1971).

There is an unexplained relation for the proximate economic cause of famine in Brazil to rise in food prices, which reduced real wages, resulting in starvation of impoverished farmers and farmhands. However, explaining the increase in food prices with supply shocks, such as harvest failure or demand shocks, is problematic. And the relationship between the economic crises, costs of the region's export products, the ruling class, and the landowners and workers are at best challenging to evaluate. The financial problems, the fall in the price of the region's export products, a kleptocratic ruling class that was experiencing progressive loss of space in national politics, social destabilisation with the ineffectiveness of the protection and submission relationship between landowners and workers, all these unknown relationships make it impossible to predict any stable quantitative relationship between the degree of stress and the extent of price rise (ROGERS, 2010).

In retrospect, the early 1870s in the Northeast can be seen as years that seemed to lead to disaster as one regional crisis pushed another inevitably. The recession of the early 1870 s was followed by a significant fall in the price of cotton, which was an important export crop for the region. The financial crisis followed, and sugar cane exports were also hit. A moléstia da cana, a cane disease that attacked the plant leaving a yellow soluble mucilage in the sugar boilers that interrupted the manufacturing operation, also contributed to the decline of the Brazilian cane plantations and the deterioration of livelihoods in the Northeast, leading to the great famine of the late 1870s (EISENBERG, 1974). Coffee continued to expand in the Southeast, while cotton, sugar, and tobacco production and exporting did not stop to contract as hundreds of thousands emigrated to the Amazon region and enslaved people were "exported" to the coffee regions (ABREU; LAGO, 2015).

The causes of the periodic droughts have long been known to be climate-related (MAGALHÃES, 2017). The issue at hand is the famines that followed. Supply shocks seem to have been at the heart of price shocks in the region according to a theory of geographical roots for the famine that followed in the 1870s and those that continued to take place at irregular intervals. According to this theory, uncertainty over the rains in a hot and dry arid interior directly influenced harvests and food supplies, blaming natural conditions, ecology for sharp fluctuations. This theory was articulated and defended by the first factfinding missions to the region. The Inspetoria de Obras Contra as Secas (IOCS) was created only in 1909. The other official responses to drought and famine in the Northeast, by and large, contended that cattle-grazing and subsistence farming that depended on seasonal rains, leading to low productivity and ever-present harvest failure risk, were responsible for the resulting famines and that the lack of development of the available resources was the main reason for the calamities (CAMPOS, 2014).

Some blamed the people themselves for the situation they were going through (GREENFIELD, 2001; HADDAD, 2018). The middle path view disputed the assumption that droughts could not be mitigated by human intervention or that nothing could be done to minimise the effects of the drought (CAMPOS, 2014). Following those initial assessments, public policies were directed to address the effects of the droughts, changing attitudes and actions, resulting in the formation of commissions and government bodies to implement relief works, at first tackling water supply issues, in what became known as the "hydraulic missions", with the commissioning of studies for the construction of reservoirs (MOLLE et al., 2009).

The question arises whether the connection of famines with the supply of water was correct or not. Rainfall patterns and average temperature changed very little in the ensuing years. The Grande Seca 
took place between 1877 to 1879 , or 1880 , the first large reservoir (açude) was commissioned by the Ministry of Agricultural Affairs in 1879. The planning project was concluded in 1882, while the dam itself was completed in 1906. In the following 75 years, infrastructure in the Northeast came from close to zero to desirable levels in most regions, including reservoirs, roads, railroads, waterways, and technical assistance in general. However, droughts and hunger continued to affect particularly subsistence farmers throughout the $20^{\text {th }}$ century negatively. The technical solution remained elusive (CAMPOS, 2014).

Would a geographical view of famine emphasising trade costs rather than harvest shocks be more appropriate to the Brazilian Northeast? From this perspective, inflation during famines would result from failures in supply chains due to deficient market infrastructure. A market failure could be held responsible for, for example, the Grande Seca famine as, relative to the scale of the harvest shock, the Brazilian domestic market was too weak to move general provisions to the most affected regions. This notion is taken from Roy (2016) and applied to the Brazilian case. If we were to emphasise the geographical approach on trade costs instead of harvest shocks, inflation would have resulted from failures in supply, which are a result of the market infrastructure. As far as I am aware, there are no statistical and econometric studies analysing the capacity of the Northeastern grain market or that of the Brazilian one to move enough quantities to the region to offset the famine of the late 1870s. One would speculate that the lack of railroads and just good roads, in general, would have made such an undertaking extremely expensive, and the buying power of the local populations would have been close to zero. The gradual improvement of the region's infrastructure along the $20^{\text {th }}$ century allowed essential food items to be moved at cheaper rates; that is, the growth in road connection led to lower trading costs and the decrease in famine-related deaths. Trade would have certainly been a mitigating factor under such conditions.

The Agreste region in the 1870s was isolated both in terms of transport and communication. Bulk transportation was almost non-existent, and the long distances affected the quality and speed of response to emergencies, such as droughts that resulted in famine-like situations (TIBURCIO, 2015). But it is not clear whether marginally speedier information, better trade, and better road infrastructure would have prevented the human and economic costs of the droughts (HANDMER et al., 2012).

Borrowing from Milton Santos (2005) and his concept of the centrality of the periphery, despite Agreste's isolation and peripherical relegation, it was paradoxically central to the Brazilian Empire (MELGAÇO; PROUSE, 2017). The same author points to the metamorphosis from a rural world to an urban one characterised by environmental conditions that no longer sustained life and resorting to an anthropomorphising allegory; he asserts that nature ceases to be friendly and becomes hostile (SANTOS, 1988). That seems to have been the case of the Brazilian Agreste in the late 1870s.

\section{THE POLITICAL HYPOTHESIS OF FAMINES IN BRAZIL: POLITICAL APPROACHES TO BRAZILIAN FAMINE CONDITIONS}

Dom Pedro II, emperor of Brazil between 1831 and 1889, ruled the country by and large through a functional representative monarchy for the wealthy and white, and despite his infamous, and maybe apocryphal quip regarding the sale of crown jewels to prevent more famine deaths in the Northeast, his government seemed to desire to do something to minimise the situation genuinely. It did very little, and the accusation that the Brazilian Imperial state did less than it could during the great famine and made things worse by its submission to British trade policy is factual and wellseated in general history textbooks.

Until the 1950s, the ecological account held strong in Brazilian economic and policy history literature: the primary cause for droughts and famines was a natural or climatic phenomenon, and that was as an axiom (ABREU, 2015). Some intellectuals and social reformers at the time believed that a perpetual weakness of the sertanejos was laid bare by the droughts and that they would only experience political and social reform once the populace and the land they occupied was reorganised in smallholder 
colonies that would produce for local needs, diminishing the grip the elites had on all aspects of life in the sertão (ABREU, 2015; BUCKLEY, 2010).

Amartya Sen, the most influential theorist of famines in the $19^{\text {th }}$ and $20^{\text {th }}$ centuries, hinged his thesis on the consequences of colonial rule, first explaining the causation of starvation and the degree of exposure of people using the 'entitlement' approach (SEN, 1976). Sen's theory establishes that price shocks may arise independently of supply shocks, resulting in a severe fall in real wages regarding food prices, ending in a famine. He does not provide a generalisable hypothesis on why price shocks may occur in the absence of supply shocks (PLÜMPER; NEUMAYER, 2007).

To Sen (1976), by not meeting its social obligations, indifference, and/or placing the responsibility in the markets, the British colonial government tolerated market failure and merchants' speculative hoarding leading to famine. Bowbrick (1986) refutes Sen's famine theory by arguing that Sen used unreliable and inaccurate statistics. However, Sen's influence in famine relief analysis permeates most scholarship in the subject. Its indictment of colonial governments' apathy, inaction, and market failures ingrained food policy into humanitarian crises (TIBURCIO, 2015). Colonialism became a byword for famine, especially in south Asia and Africa.

His view that famine and drought relief should be a contractual obligation and that inadequate relief considered a breach of that social contract underlies most subsequent research. Sen's theory limits the reach of any ecological account. It points to inequality in "entitlement to food" in any significant food crisis as the right place to look for explanations to the effects of one (OSMANI, 2000). Sen shifted lay and expert views against free and less regulated markets (SEN, 1983). However, Sen's explanation is not supported by historical evidence (PEACOCK, 2010; RAVALLION, 1987).

Before Sen, Castro (1946, 1952), influenced by Social Catholicism, Myrdal (1968)'s poverty cycle, and La Blanche (1954)'s geography linking biology and sociology - connecting human nutrition and the characteristics of social organisation - rejected many of the socio-economic beliefs regarding drought and famine that prevailed in his time, some of which are still fashionable nowadays (BRADY, 2008; MISSIO et al., 2015; TARANTO, 1980). The author espoused an empirical theory that went against some of the tenets of the positivist thought that dominated Brazilian drought and famine response from the imperial period to the 1960s. Castro $(1946,1952,1954)$ strengthened his hypothesis that hunger in the Brazilian Northeast was neither related to the quantity of food nor the number of inhabitants; instead, it was a wealth distribution issue, intimately associated with the increasing concentration of land in the hand of a few (VASCONCELOS, 2008). He advocated that expanding food production was not the solution but rather the distribution of resources and land (CASTRO, 1967). He also mapped the distribution and concentration of hunger in Brazil to discredit prejudiced causes that are still routinely used contemporarily, especially the supposed idleness of the Northeastern people and the climate (CASTRO, 1952).

To Castro (1960), local and national politics and unbalanced social and economic relations were behind hunger, malnutrition, and not natural factors. "Hunger is not a natural phenomenon, but an artificial product of defective economic conditions. A product of human creation and therefore liable to being eliminated by the will of man himself" (CASTRO, 1960, p. 60). However, some of Castro's correlations and explanations were spurious, and he was not too concerned about "the canons of scientific procedure" (MAGALHÃES, 1997, p. 16). He was, above all, an activist against hunger (FAIRCHILD, 1952).

\section{THE NATURE OF THE STATE AND DROUGHT AND FAMINE IN BRAZIL}

The nature of the state cannot explain the cessation of famines in Brazil. The end of the imperial period in 1889 had little to no effect on the economy and social fabric of the Brazilian Northeast. In 1876-79, it was easy to underestimate supply shocks and overestimate market failures as the poor population was 
nearing destitution in most drought-prone regions. A prolonged mismatch between people and food production and trade peaked when the drought struck (GREENFIELD, 1992).

There were diminishing returns to agriculture in much of the Northeast, especially in Ceará in the 1870s. As sharecroppers, landless farmers and farmhands struggled to pay their rents with crops and labour. Survival was conditioned by a limited spectrum of livelihood options: subsistence and small-scale farming, and hired labour to landlords, apart from seasonal work in sugarcane and cotton plantations in some regions (BUCKLEY, 2010).

The nature of the state in Brazil and famine, and whether they may be classified as manmade and made worse by the slow hand of the state, is the question regarding the intentionality of the failure, that is, of the state failing to act. Regarding the 1877-79 drought and famine, seeing it as a "manmade" crisis entails claiming that there was deliberate state failure and not simply economic issues about production in a context of repeated droughts. To advocate this hypothesis, one would have to assume that the Brazilian state was given an exogenous level of state capacity, equipped to provide relief effectively, but that it had calculatingly underutilised it (HALL-MATTHEWS, 2008). And importantly, to support this view, politicians would have to be free agents and, therefore, liable in case of inaction, as famine relief would have been a matter of free choice. To evaluate such a situation in 1870s Brazil is an almost impossible task due to a lack of data for the period (FAGAN, 2008).

But could the Brazilian state have acted to prevent the 1877-79 famine effectively? Droughts and famines compromise state capacity. No matter how well prepared, as variability in the scale of natural disasters is an intrinsic feature, no preparedness or size of insurance can genuinely cope with a systemic disaster. In other words, the issue in Brazil was systemic, as the variability of scale entails that those government agents given the responsibility to prepare state capabilities were systematically underprepared. The Imperial government's presence in the Northeast in the 1870s, as in most of the country except in some coastal urban centres, was sparse. The Empire of Brazil was a decentralised monarchy, with each province having a provincial legislative assembly that had much autonomy in varied matters. The national government appointed the president of the province. Still, the day-to-day affairs of the province were run by the de facto governor, the vice-president who was elected by the local, provincial assembly (VALENÇA, 1999). Provincial politics was a patronage game involving the exchange of favours between the most powerful families of each region, the "colonel's regime", a local strongman that defined everything in their area (JANOTTI, 1981).

The droughts and famine of the 1870s were not unforeseeable, but there were no insurance policies or any preparation in place, either by the local elites or the imperial government. The situation weakened the already weak state. Variability of scale is an ever-present problem for historians and policymakers alike. Although the class of events predicted to occur is not new, the scale is always a novelty (WILHITE et al., 2014). In this way, in the 1870s, the Brazilian government and the people were unprepared as matching state and societal capacity with the scale of the problem was a continued failure.

In the 1870s and subsequent decades, the government's reaction took a generation to take effect, as the state's presence and resources to collect data and act on it were limited and poorly managed. In December 1877, the Emperor created the Imperial Commission to study the causes and actions to fight drought and famine in the Northeast. The commission's report recommended the construction of three railways, 30 dams, meteorological observation posts, and the opening of a canal linking the largest regional river, the São Francisco, to the Jaguaribe River, apart from the importation of camels (RINALDO, 2017).

The Brazilian Imperial government in the Northeast of Brazil in the 1870s was a weak state; the density of its network of local administration was at best flimsy, and at worse, non-existent, with minimal penetration in the deepest Agreste. Representatives of the state and imperial government rarely visited the worst affected areas, and travel was difficult. The provincial government only started to become aware of the seriousness of the situation when starving; emaciated retirantes started to crowd coastal towns (NEVES, 2000). Those that survived trekking through the deserted interior were encouraged to migrate to the Amazon region, to the Southeast - Rio de Janeiro and São Paulo, anywhere, as long as it was far away (FAGAN, 2009). 
Notwithstanding Dom Pedro II pledge to end droughts in the Northeast, his crown's means were limited: the provincial and imperial governments had scant reliable and scientifically collected data, inadequate transport and communication infrastructure, and corresponding fiscal capacity. Still, the Crown was fiscally solvent for most of the Imperial period (1822-1889), as "the Brazilian fiscal policy, as it was demonstrated [...] [exhibited] a genuinely 'Ricardian' behaviour, realising fiscal adjustments and utilising the internal and external debt efficiently as a way to attain the intertemporal balance." (RUIZ-DE-GAMBOA; SUMMERHILL, 2009, p. 3).

But, apart from that, for much of the late Empire and the First Republic, Brazil was beset by oligarchic patrimonialism and a long-ingrained system of electoral clientelism (QUIMPO, 2005). At the same time, local public and private resources were limited, as the Northeast's growth rate was close to zero, or just negative for the 1822 to 1850 period, followed by marginally better growth rates between 1850 and the early 1870 s, and again negative growth rates between 1875 and 1889 (ABREU; LAGO, 2010).

Although the 1877-79 drought compromised state capacity, it did lead to some organisation by the state to prevent the worst with the introduction of a relief system based mostly on regional public works (CAMPOS, 2015). Dandaro and Marcondes (2018) show that the Ministry of Public Works (MOP) expenditures until 1914 were realised in periods of drought. Most of them were directed to relief work to those directly affected by the droughts. The first drought in the First Republic took place from 1898 to 1900 in the Campos Sales government. The federal government did very little, denying most of the Northeastern governors' requests for aid, claiming they would destabilise the budget (VILLA, 2000).

Information and scientific knowledge about weather and agriculture were starting to be seen as indispensable to battle droughts and famines. An increase in the volume of data produced became available to the Imperial cabinet (GREENFIELD, 1992). Gonçalves (2018) argues that the Brazilian Empire spurned by Dom Pedro II followed the scientific search for a markedly positivist solution to the drought and famine conundrum. The Brazilian state pursued a hydraulic solution to the water shortage issue and related matters from 1877 to the early 1950s (MOLLE et al., 2009).

The first general director of the IOCS, Arrojado Lisboa, understood the relevance of information regarding technical and scientific knowledge and invested in research that resulted in valuable studies that guided government policy (CAMPOS, 2015). Information was irrevocably established as a basis for policy formulation (CAMPOS, 2014).

But, back in 1877-79, the geographical distances between the worst affected areas and the state seats of power made information about local living conditions, economic, market and trade networks limited and infrequent, affecting the quality and speed of response to droughts and famines in a context that was already marked my inefficient and insulated government entities. The news of the situation claimed some contemporary accounts, only reached the state capitals with the flagelados, as thousands fled to coastal towns searching for food and shelter (GREENFIELD, 1992).

Nevertheless, there was some information gathering and dissemination effort, especially one promoted by a firm belief in the newish positivist science, as printed on the $O$ Retirante newspaper in March 1878:

Let us all trust Providence but let us not rest. To prepare tomorrow the effect of indolence, the society that rests today accumulates evils that, duplicated, sometimes become incurable. Therefore, it is necessary to continue to study the determining causes of drought in the regions now plagued by this scourge and prepare the required elements of resistance for the future. The medicine that has to cure Ceará and its northern sisters are not, and cannot be, hydropathic; it is a medicine of high politics, predictions, studies, courage, and patriotism. (O RETIRANTE, 1878, p. 2-3; GONÇALVES, 2018, p. 516). [Translation by the author].

Weather prediction gained importance in famine prevention in Brazil as meteorological stations and observation were part of the proposals of the Imperial Commission of 1856. Experts gathered at a 
Historical and Geographical Brazilian Institute (IHGB) session recommended the establishment of meteorological stations that would observe and record phenomena, help predict droughts, and better prepare a government response. Weather prediction would be of critical importance to prevent future famine-conducive conditions (BUCKLEY, 2010). But they were debating, and no actual proposals or plans resulted from the exchanges except for the Açude do Cedro, the Cedar Weir, in Quixadá, state of Ceará. No action was taken for decades to come.

A smallpox epidemic accompanied the 1877-79 drought in Fortaleza, the capital of the state at the epicentre of the famine (COSTA, 2004). One of the catalysing factors in the high number of deaths in the 1877-79 famine was the lack of preventive anti-epidemic measures, especially in the agglomerations to which some of the flagelados were forced to stay (BARRETO et al., 2011). The relationship between social crises, famines, and epidemic diseases is still an ongoing debate with ample literature, but there is much evidence of their lethal interplay (ARNOLD, 1993; HIONIDOU, 2002).

\section{MIGRATIONS, CULTURE AND THE STATE}

In the 1877-79 drought, the Brazilian empire facilitated emigration to the Amazon, allowing part of the population to flee the drought and famine and work in the rubber cycle period. In 1915, the Republican state quarantined some internally displaced people in concentration camps. The camps were laid out in a swampy region in the district of Otávio Bonfim and Senador Pompeu, Ipu and Crato in the Northeastern state of Ceará. These hunger camps were designed to confine drought-affected northeasterners. Some 8 thousand people of all ages were kept in poor housing conditions, with little or no clean water; most were jobless and constantly hungry to keep the capital free of the chaos, misery, disease, and dirt that the flagelados brought with them (TEÓFILO, 1980). Behind the creation of camps were the beliefs of politicians and their advisers that were influenced by the hygienist and eugenicist pseudo-science that permeated much of public policy in Brazil in the early 20th century (FERREIRA; DANTAS, 2001).

Famines lead to deaths directly by diminishing food availability. Higher prices make food unaffordable and expose the already weakened and vulnerable population to contaminated water and food sources. Hunger weakens the immune system, and "between starvation and death, there is nearly always disease" (WORLD HEALTH ORGANIZATION, 2017, p. 30). Advances in anti-epidemic measures and modern medicine, in general, were crucial to an abrupt decline in famine deaths in the $20^{\text {th }}$ century (FIELDING, 1999).

Some state and civil society agents in Brazil believed that most of the fault for the misery and death in the Northeast was to be found with the people themselves: they were lazy and unindustrious. Even for avant-garde scientists of the time, such as, André Rebouças and José Américo dos Santos, the sertanejos needed to be rescued from themselves (CAMPOS, 2014). As the drought weakened the state capacity of an already sparsely present state, the sheer scale of the event rendered private and local insurance strategies ineffectual. There was nothing feasible to be done by humans to diminish the intensity of the drought itself. However, channels, reservoirs and forestation could help supply people and livestock with essential water supply (CAMPOS, 2014).

As for its effects on human beings and their livestock, the usual storing of harvest surplus, savings from previous good seasons and trade were insufficient to carry the population of the provinces most affected - Ceará, Piauí, the Rio Grande do Norte, Pernambuco, Paraíba, and Alagoas - through a single drought year, much less through 3 consecutive ones. Private grain stocks in those states were just enough in average years, and some staples were imported from the South. At best, the Sertanejos diet was poor, rapadura (unrefined cane sugar), cassava flour, and sun-dried beef. But as the drought prolonged and the stigma of consuming palm as it served as cattle feed was waning, whatever palm available was devoured by humans and cattle (SEDREZ, 2008). 
In the 1870s Brazil, one could ask if the imperial regime respected a social contract, and the answer would be that it did not take its obligation very literally. However, the 1877 drought was the necessary trigger for the Empire to try and do something about the continuing economic decline of the Northeast, for example, through the implementation of the Pompeu-Sinimbú Project, named after the two senators that proposed it (SOUZA, 2019). The project was sponsored by the Northeastern elites with the support of the Pedro II government, led by the Chief of Cabinet João Sinimbu, and aimed at equating economic differences between the North (Northeast) and the South of Brazil (SOUZA, 2015). In it, one sees the condensation of ideas of market failure, culture, and charity in a nutshell about Brazil as a whole and a self-image of the Northeastern Brazilian elites of the period. All the same, philanthropy failed as the sponsors' capacity was reduced (GREENFIELD, 1986).

The project consisted of taking advantage of the very misfortune of the victims of the drought, exploiting them in what was regarded as "useful work". The two senators proposed an indirect aid policy. To receive government assistance, the sertanejos needed to pay for it with their labour, changing what had been a right provided by the law into work in exchange for aid policy. In the long run, the idea was to compensate for the economic imbalance between the North and the South of Brazil with a policy that used the drought and the famine-like conditions it brought as a driver of economic progress through the exploitation of workers rendered destitute in public works (SOUZA, 2019). Public charity in the first republic took centre stage, however, though it also fell short of the needs of the flagelados (NUNES, 2009).

\section{CONCLUSIONS}

The study of political theories and factors, natural phenomena - such as climate, topography, and market viability - do not investigate the causes of the drought of 1877-1879. There is little or no research or even reliable records on most of the critical factors that satisfactorily explain why the drought and famine episodes were so impactful in that period.

The famine associated with the Grande Seca, the Great Drought of 1877-1879 in the Brazilian Northeastern, was both political and geographical at its origins. "Political", to the extent that an unknowable weight of the famine was a result of imperial politics. Present research fails to explain the uncommonness of extreme famine-like conditions for most of the imperial period. It presumes that the capacity of the Brazilian imperial state to alleviate famine leading conditions was checked only by its intentions to act, even though it is also implausible as the fundamental concept of the state is either undeveloped or one-dimensional in most of the literature in the field. The geographical weight is confirmedly present, to the extent that the weather shocks and natural and terrain obstacles to trade conjointly led to the famine.

I have also suggested in this article that the effects of geographical or political causes depended on available information and knowledge, which constrained the Brazilian state's capacity to act during the 1877-79 Grande Seca. More information collection and knowledge, greater preparation and more specialised response led to less-lethal droughts, with fewer hunger-related deaths, albeit not to their eradication. This hypothesis does not disregard the relevance of either market strength or swings in the political economy ideology behind the set of possible causation drivers for famine conditions in the Brazilian Northeast in the 1870s. It simply adds a third significant element that studies of political and geographical views generally tend to underestimate.

\section{ACKNOWLEDGEMENTS}

I thank an anonymous reviewer for critically reading the manuscript and suggesting substantial improvements. 


\section{REFERENCES}

ABREU, A. A. Dicionário histórico-biográfico da Primeira República: 1889-1930. Rio de Janeiro: FGV, 2015.

ABREU, M. P.; LAGO, L. A. C. A economia brasileira no Império, 1822-1899. In: ABREU, M. P (Org.) A Ordem do Progresso: dois séculos de política econômica no Brasil. Rio de Janeiro: Atlas, 2015, p. 1-28.

ACEITUNO, P. et al. The 1877-1878 El Niño episode: associated impacts in South America. Climatic Change, n. 92, p. 389416, 2009.

ALBUQUERQUE JÚNIOR, M. de. Preconceito contra a origem geográfica e de lugar: as fronteiras da discórdia. São Paulo: Cortez Editora, 2017.

ALVES, J. História das Secas (Século XVII a XIX). Fortaleza: Fundação Waldemar Alcântara, 2003 [1953].

ARNOLD, D. Social crisis and epidemic disease in the famines of nineteenth-century India. Social History of Medicine, New York, v. 6, n. 3, p. 385-404, Dec. 1993.

BARRETO, M. L. et al. Successes and failures in controlling infectious diseases in Brazil: social and environmental context, policies, interventions and research needs. Lancet, London, v. 377, n. 9780, p. 1877-1889, 2011.

BÉRTOLA, L.; OCAMPO, J. A. The Economic Development of Latin America since Independence. New York: Oxford University Press, 2012.

BLAKE, S. S. The Medicalization of Nordestinos: public health and regional identity in northeastern Brazil, 1889-1930. The Americas, v. 60, n. 2, Oct. 2003, p. 217-248.

BOWBRICK, P. The causes of famine: a refutation of Professor Sen's theory. Food Policy, v. 11, n. 2, p. 105-124, May 1986.

BRADY, B. V. Essential Catholic Social Thought. Maryknoll: New York, 2008.

BRITO, S. et al. Frequency, duration and severity of drought in the Semiarid Northeast Brazil region. International Journal of Climatology, Boston, MA, v. 38, n. 2, p. 517-529, Feb 2018.

BUCKLEY, E. E. Drought in the sertão as a natural or social phenomenon: establishing the Inspetoria Federal de Obras Contra as Secas, 1909-1923. Boletim do Museu Paraense Emílio Goeldi, Ciências Humanas, Belém, v. 5, n. 2, p. 379-398, 2010.

CAMPOS, J. N. B. Secas e políticas públicas no semiárido: ideias, pensadores e períodos. Estudos Avançados, São Paulo, v. 28, n. 82, p. 65-88, 2014.

CAMPOS, J. N. B. Paradigms and Public Policies on Drought in Northeast Brazil: a historical perspective. Environmental Management, New York, v. 55, n. 5, p. 1052-1063, Jan 2015.

CAMPOS, J. N. B. Secas e políticas públicas no semiárido: ideias, pensadores e períodos. Estudos Avançados, São Paulo, v. 28, n. 82, p. $65-88,2014$

CARDIM, F. Tratados da terra e gente do Brasil. São Paulo: Ed. Itatiaia, 1980.

CASTRO, J. O Livro negro da fome. São Paulo: Brasiliense, 1960.

CASTRO, J. Sete Palmos de Terra e um Caixão: ensaio sobre o Nordeste, área explosiva. São Paulo: Brasiliense, 1967.

CASTRO, J. The Geography of Hunger. Boston: Little, Brown and Company, 1952.

COSTA, M. C. L. Medical theories and urban management: Fortaleza's 1877-79 drought. História, Ciências e Saúde. Rio de Janeiro, v 11, n. 1, p. 57-74, Jan-Apr. 2004.

DANDARO, F. M.; MARCONDES, R. L. Obras públicas no contexto regional: secas e gastos no Nordeste brasileiro (18601940). Revista Econômica do Nordeste, Fortaleza, v. 49, n. 3, p. 113-127, 2018. 
DENG, F. M.; MINEAR, L. The Challenges of Famine Relief: emergency operations in Sudan. Washington, D.C.: Brookings Institution, 1992.

DUFFIELD, M. Complex Emergencies and the Crisis of Developmentalism. Institute of Development Studies Bulletin: Linking Relief and Development, Brighton, v. 25, n. 4, p. 1-15, 1994.

EISENBERG, P. L. The Sugar Industry in Pernambuco: modernization without change, 1840-1910. Berkeley: University of California Press, 1974.

FAGAN, B. Floods, Famines, and Emperors: El Nino and the fate of civilizations. New York: Basic Books, 2008.

FAIRCHILD, H. P. The Geography of Hunger, by Josué de Castro. Review. Social Forces, New York, v. 31, n. 1, p. 82-84, Oct 1952.

FERREIRA, A. L. A.; DANTAS, G. A. F. Indesejáveis na cidade: as representações do retirante da seca (Natal, 1890-1930). Scripta Nova - Revista Electrónica de Geografia y Ciencias Sociales, Barcelona, v. 94, n. 96, Aug 2001. Available at: http:// www.ub.edu/geocrit/sn-94-96.htm. Accessed on: 10 Mar. 2020.

FIELDING, J. E. Public Health in the Twentieth Century: advances and challenges. Annual Review of Public Health, San Mateo, CA, v. 20, p. xiii-xxx, May 1999.

FURTADO, C. M. The Economic Growth of Brazil: a survey from colonial to modern times. Berkeley: University of California Press, 1971.

GONÇALVES, P. C. O mandacaru não floresceu: a ciência positivista a serviço do combate à seca de 1877-1879. História, Ciências e Saúde, Rio de Janeiro, v. 25, n. 2, p. 515-539, April-June 2018.

GREENFIELD, G. M. Migrant Behavior and Elite Attitudes: Brazil's great drought, 1877-1879. Philadelphia: Academy of American Franciscan History, 1986.

GREENFIELD, G. M. The Great Drought and Elite Discourse in Imperial Brazil. Hispanic American Historical Review, Durham, NC, v. 72, p. 375-400, 1992.

GREENFIELD, G. M. The Great Drought and Elite Discourse in Imperial Brazil. The Hispanic American Historical Review, Durham, North Carolina, v. 72, n. 3, p. 375-400, Aug. 1992.

GREENFIELD, G. M. The realities of images: imperial Brazil and the great drought. Philadelphia: The American Philosophical Society, 2001.

HADDAD, E. A. Regional Inequality and Structural Changes: lessons from the brazilian. New York: Routledge, 2018.

HALL-MATTHEWS, D. Inaccurate Conceptions: disputed measures of nutritional needs and famine deaths in colonial India. Modern Asian Studies, Cambridge, v. 42, n. 6, p. 1189-1212, Nov 2008.

HANDMER, J. et al. Changes in impacts of climate extremes: human systems and ecosystems. In: FIELD, C. B. et al. (Ed.). Managing the Risks of Extreme Events and Disasters to Advance Climate Change Adaptation. A Special Report of Working Groups I and II of the Intergovernmental Panel on Climate Change (IPCC). Cambridge, UK, and New York, NY, 2012. p. 231-290.

HASELL, J.; ROSER, M. Famines. Our World in Data. 2013. Available from: https://ourworldindata.org/famines. Accessed on: 10 Jan. 2020.

HIONIDOU, V. Why Do People Die in Famines? Evidence from Three Island Populations. Population Studies, London, v. 56, n. 1, p. 65-80, March 2002.

JANOTTI, M. L. M. O coronelismo: uma política de compromissos. São Paulo: Brasiliense, 1981.

LA BLANCHE, P. V. de. Princípios de Geografia Humana. Lisboa: Cosmos, 1954.

MADDISON, A. Brazilian Development Experience from 1500 to 1929. Unpublished. 1992. 
MAGALHÃES, A. R. Life and Drought in Brazil. In: NYS, E.; ENGLE, N.; MAGALHÃES, A. R. (Org.). Drought in Brazil Proactive Management and Policy. New York: CRC Press, 2017, p. 1-18.

MAGALHÃES, R. Fome: uma (re)leitura de Josué de Castro. Rio de Janeiro: Editora Fiocruz. 1997.

MELGAÇO, L.; PROUSE, C. L. Milton Santos and the Centrality of the Periphery. In: MELGAÇO, L.; PROUSE, C. L. (Ed.) Milton Santos: a pioneer in critical geography from the global south. Pioneers in Arts, Humanities, Science, Engineering, Practice, v. 11. Cham, Switzerland: Springer, 2017. p. 1-24.

MELO, E. C. O norte agrário e o Império, 1871-1889. Rio de Janeiro: Editora Nova Fronteira, 1984.

MISSIO, F.; JAYME JUNIOR, F. G.; OREIRO, J. L. The structuralist tradition in economics: methodological and macroeconomics aspects. Brazilian Journal of Political Economy, v. 35, n. 2, p. 247-266, 2015.

MOLLE, F. Marcos históricos e Reflexões sobre a Açudagem. Recife: Sudene, DPG. PRN. HME, 1994.

MOLLE, F.; MOLLINGA, P. P.; WESTER, P. Hydraulic Bureaucracies and the Hydraulic Mission: flows of water, flows of power. Water Alternatives, Montpellier, v. 2, n. 3, p. 328-349, 2009.

MYRDAL, K. G. Asian Drama: an inquiry into the poverty of nations. New York: Pantheon, 1968.

NAVARRO, J. A. et al. Cartas avulsas, 1550-1568. Belo Horizonte: Itatiaia; São Paulo: Ed. da USP, 1988.

NEVES, F. C. A multidão e a história: saques e outras ações de massas no Ceará. Rio de Janeiro: Relumé Dumará. FortalezaCE: Secretaria de Cultura e Desporto, 2000.

NEWSON, L. A. The Demographic Collapse of Native Peoples of the Americas, $1492-1650$. Proceedings of the British Academy, London, v. 81, p. 247-288, 1993.

NUNES, F. A. Interesses e sentimentos caritativos nas ações de filantropia no Brasil (Caso da seca de 1877). Revista Brasileira de História e Ciências Sociais, Carreiros.

Ó GRÁDA, C. Making Famine History. Journal of Economic Literature, Pittsburgh, PA, v. 45, n. 1, p. 5-38, 2007.

OSMANI, S. R. The entitlement approach to famine: an assessment. In: BASU, K.; PATTANAIK, P.; SUZUMURA, K. Choice, Welfare, and Development: a festschrift in honour of amartya K. Sen. New Delhi: Oxford University Press, 2000, p. 253-294.

PEACOCK, M. S. Starvation and Social Class: amartya sen on markets and famines. Review of Political Economy, London, v. 22, n. 1, p. 57-73, 2010.

PLÜMPER, T.; NEUMAYER, E. Famine mortality, rational political inactivity, and international food aid. PSPE working papers, London, n. 2, n. 1, p. 50-61, 2007.

QUIMPO, N. G. Oligarchie Patrimonialism, Bossism, Electoral Clientelism, and Contested Democracy in the Philippines. Comparative Politics, v. 37, n. 2, p. 229-250, Jan 2005.

RAVALLION, M. Markets and Famines. Oxford University Press: Oxford, 1987.

Rio Grande, v. 1, p. 1-11, 2009.

ROGERS, T. D. The Deepest Wounds: a labor and environmental history of sugar in Northeast Brazil. Chapel Hill: The University of North Caroline Press, 2010.

ROY, T., Were Indian Famines "Natural” or "Manmade"? Economic History Working Papers, London, n. 243, 2016. Available at: https://www.Ise.ac.uk/Economic-History/Assets/Documents/WorkingPapers/Economic-History/2016/WP243.pdf.

RUIZ-DE-GAMBOA, U.; SUMMERHILL, W. Reestimating the Brazilian public debt/GDP ratio: "fiscal skeletons" and "new Ricardian" behavior. Prepared for the Conference on "Latin America Economies: History and Globalization," 24th and 25th of April 2009, UCLA. 
SANTOS, M. Metamorfoses do espaço habitado. São Paulo: Hucitec, 1991.

SANTOS. M. Urbanização Brasileira. São Paulo: Editora da Universidade de São Paulo, 2005.

SANTOS, R. Os sertaníadas - de 1900 a 2015 (500 anos de hipocrisia na história do Brasil): a epopeia dos esquecidos nos sertões. Porto Alegre: Revolução eBook. 2017.

SEDREZ, L. F. Environmental History of Modern Latin America. In: HOLLOWAY, T. (Ed.) The Blackwell Companion to Latin American History. Malden, MA: Blackwell, 2008.

SEN, A. Famines as Failures of Exchange Entitlements. Economic and Political Weekly, Delhi, v. 11, n. 31/33, p. 12731280, 1976.

SEN, A. Poverty and Famines: an essay on entitlement and deprivation. Oxford University Press: Oxford, 1983.

SENA, A. et al. Drought in the Semiarid Region of Brazil: exposure, vulnerabilities and health impacts from the perspectives of local actors. PLOS Currents, Bethesda MD, v. 1, 2018. Available at: https://www.ncbi.nlm.nih.gov/pmc/articles/ PMC6279460/.

SINGH, D. et al. Climate and the Global Famine of 1876-78. Journal of Climate, v. 31, n. 23, p. 9445-9467, 2018.

SINGH, D. et al. Climate and the Global Famine of 1876-78. Journal of Climate, Boston, n. 31, p. 9445-9467, Dec. 2018.

SOUZA, J. W. F. Dry Seasons and Public Aid in Ceará Illness, Poverty and Violence (1877-1932). Projeto História, São Paulo, n. 52, p. 178-219, 2015.

SOUZA, J. W. F. The Pompeu Sinimbu Project and the economic imbalance between the Northeast and the Central South of Brazil (1877-1901). Revista Econômica NE, Fortaleza, v. 50, n. 3, p. 49-68, Jul-Sep 2019.

STAHL, R. M. The Economics of Starvation: laissez-faire ideology and famine in Colonial India. In: THORUP, M. (Ed.) Intellectual History of Economic Normativities. New York, 2016. p. 169-184.

TARANTO, G. Societá ed Sottosviluppo nell'opera di Josué de Castro. Cahiers Internationaux d'Histoire Economique et Sociale. Geneve: Librairie Droz, 1980.

TEÓFILO, R. M. A Seca de 1915. Fortaleza: Edições UFC, 1980.

TIBURCIO, J. A. P. Entre a Fome e a burocracia: políticas públicas e a segurança alimentar na Índia. Doctoral Thesis (Doctoral Thesis in Sustainable Development) - Center for Sustainable Development, University of Brasilia, Brasília, 2015, 310 p.

VALENÇA, M. M. Patron-Client Relations and Politics in Brazil: an historical overview. Research Papers in Environmental and Spatial Analysis Working Paper, n. 58, Dec 1999.

VASCONCELOS, F. A. G. Fighting hunger in Brazil: a historical analysis from Presidents Vargas to Lula. Revista de Nutrição, Campinas, v. 18, n. 4, p. 439-457, July-August 2005.

VASCONCELOS, F. A. G. Josué de Castro and The Geography of Hunger in Brazil. Cadernos de Saúde Pública, Rio de Janeiro, v. 24, n. 11, p. 678-4464, Nov 2008.

VILLA, M. A. Vida e morte no sertão. História das secas no Nordeste nos séculos XIX e XX. São Paulo: Ática, 2000.

WILHITE, D. A.; SIVAKUMAR, M. V. K.; PULWARTY, R. Managing drought risk in a changing climate: the role of national drought policy. Weather and Climate Extremes, Amsterdam, v. 3, p. 4-13, Jun 2014.

WORLD HEALTH ORGANIZATION. Ten years in public health, 2007-2017: report by Dr Margaret Chan, Director-General. Geneva World Health Organization, 2017. 